Western North American Naturalist 69(3), (C) 2009, pp. 309-318

\title{
FORMATION AND CONTENTS OF YELLOW-PINE CHIPMUNK (TAMIAS AMOENUS) WINTER LARDERS
}

\author{
Kellie M. Kuhn ${ }^{1,3}$ and Stephen B. Vander Wall ${ }^{2}$
}

\begin{abstract}
Despite much attention to the foraging habits and hibernation patterns of food-storing mammals, little is known about the contents of winter larders under natural conditions or how animals prepare a winter larder. Here we describe the contents of 15 yellow-pine chipmunk (Tamias amoenus) winter larders from 3 different years and describe the movement of scatter-hoarded seeds into larders. We found larders by locating 14 radio-collared chipmunks in their winter dens. One additional larder was found by tracking the movement of seeds labeled with radioactive scandium-46 from scattered caches into the larder. Chipmunks formed winter dens and rapidly provisioned winter larders in the fall, just before the onset of winter. Surface caches were dynamic, with seeds residing in $1-6$ cache sites $(\bar{x}=2.6, s=1.1)$ before being found in the larder. Distances from scattered caches to the winter larder were $34.5 \mathrm{~m}(s=17.1)$. Contents of winter larders consisted of pine and shrub seeds. In 14 of the 15 larders, pine seeds contributed most to the size and caloric content of larders. Pine seeds and other seeds found in winter larders were produced by plants 2-4 months before the onset of winter. We conclude that if yellow-pine chipmunks did not scatter-hoard seeds during summer and autumn, seeds would not have been available for use in winter larders.
\end{abstract}

Key words: caloric content, larder-hoarding, scatter-hoarding, Tamias amoenus, Sciuridae, winter larder, yellow-pine chipmunk.

Many small mammals are seasonally dormant (e.g., hibernators) and use metabolic depression to reduce energy consumption during periods of food scarcity (Lyman et al. 1982, Tauber et al. 1986, Ultsch 1989). Animals become dormant when the cost associated with being active is higher then the cost of hibernating (Michener 1984, Bucks and Barnes 1999, Neuhaus et al. 1999, Humphries et al. 2003). Mammals that hibernate store food, accumulate body fat, or do both during the active season to provide themselves sufficient energy to survive the winter. Some small mammals circumvent possible energy storage limitations by storing food rather than fat (French 1988, McNab 2002). For food-storing species, the contents of winter larders are critical for winter survival and can influence body condition in the spring (e.g., Barnes 1984, Place et al. 2002).

Sciurid rodents are a group of small mammals for which hibernation has been well studied (e.g., Stebbins and Orich 1977, MacLean 1981, Wrazen and Wrazen 1982, Barnes 1984, Michener 1984, Geiser and Baudinette 1990, Geiser et al. 1990, French 2000, Humphries et al. 2001, 2003, Hut et al. 2002, Place et al. 2002, Landry-Cuerrier et al. 2008). Despite much research on the physiology of hibernation and the importance of the winter larder in overwinter survival, few studies have described the contents of larders (summer larders: Allen 1938, Hawbecker 1940, Jennings 1975, Elliott 1978, Kawamichi 1989; winter larders: Broadbooks 1958, Kuhn and Vander Wall 2008), and little is known about how these animals prepare a winter larder. In order to fully understand hibernation patterns and the physiology of hibernation in food-storing hibernators, it is important to know how much food is stored in winter larders under natural conditions.

Yellow-pine chipmunks (Tamias amoenus, 40-50 g) are scatter-hoarding sciurid rodents that are seasonally dormant. In the active season, yellow-pine chipmunks gather seeds as they become available and store them in many scattered cache sites (Broadbooks 1958). To survive the winter, chipmunks sharply decrease their activity and food consumption and conserve energy by using intermittent bouts of torpor (Stebbins and Orich 1977, French 2000). Yellow-pine chipmunks do not accumulate

\footnotetext{
${ }^{1}$ Department of Biology, University of Nevada, Reno, Reno, NV 89557.

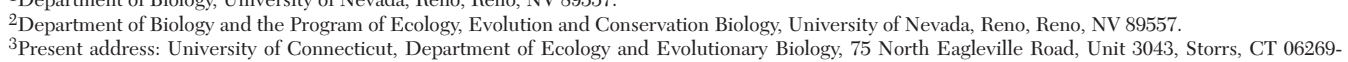
3043. E-mail: kellie.kuhn@uconn.edu
} 
body fat before hibernation (Tevis 1952). Instead they collect a large number of scattered food items and store them in a single winter larder (Broadbooks 1958, this study). While in their winter dens, chipmunks arouse periodically to eat and excrete waste. Without stored food, chipmunks could not survive the winter (Aunfriev and Arkhipov 2004). Here we describe temporal and spatial movement of scatter-hoarded seeds into larders and document contents of winter larders of yellow-pine chipmunks.

\section{METHODS}

\section{Study Site}

We conducted this study in the Whittell Forest and Wildlife Area $\left(39^{\circ} 15^{\prime} 64^{\prime \prime} \mathrm{N}\right.$, $119^{\circ} 52^{\prime} 49^{\prime \prime} \mathrm{W}$ ) on the east slope of the Carson Range in western Nevada at an elevation of 1975-2000 m, about $30 \mathrm{~km}$ south of Reno. Vegetation at the site consisted of open Jeffrey pine (Pinus jeffreyi) forest with lodgepole pine (Pinus contorta) and a shrub understory of antelope bitterbrush (Purshia tridentata), greenleaf manzanita (Arctostaphylos patula), tobacco brush (Ceanothus velutinus), and Sierra bush chinquapin (Castanopsis sempervirens). Seven species of sciurid rodents are found on the study site: yellow-pine chipmunks, longeared chipmunks (Tamias quadrimaculatus), lodgepole chipmunks (Tamias speciosus), golden-mantled ground squirrels (Spermophilus lateralis), California ground squirrels (Spermophilus beecheyi), Douglas squirrels (Tamiasciurus douglasii), and western gray squirrels (Sciurus griseus). Among all rodent species found on the study site, yellow-pine chipmunks, deer mice (Peromyscus maniculatus: Muridae), and golden-mantled ground squirrels are most abundant.

\section{Larder Formation from Scatter-hoarded Caches}

It is rare to observe seeds being recovered and then recached. Therefore, to demonstrate the movement of seeds among scatter-hoarded caches and the movement of seeds from scattered cache sites into a winter larder, we include data collected as part of a broader study on the scatter-hoarding behavior of yellow-pine chipmunks (Vander Wall 2002, 2003). To track the movements of seeds, we located 1036 seed caches labeled with radioactive scandium-46 in the fall of 2000 . We used 3 species of pine seeds (sugar pine, Pinus lambertiana; Jeffrey pine; and ponderosa pine, Pinus ponderosa). Sugar pine and ponderosa pine are native to the area, but they did not occur on our study site. Each seed was uniquely numbered with indelible ink, which allowed us to follow the fates of individual seeds. Few other pine seeds were produced by trees in the vicinity in autumn 2000 .

Radioactive seeds were deployed under a single Jeffrey pine tree (hereafter referred to as the source tree) between 9 and 11 September 2000 (methods detailed in Vander Wall 2002 , 2003). On 12 September, we began surveying the area around this source tree with Geiger counters to locate cached and eaten seeds. When we located a cache, we excavated the seeds, recorded the numbers on them, buried them at the cache site at the original depth, and mapped the cache location relative to the source tree using cardinal directions as $\mathrm{x}$ - and $\mathrm{y}$-axes. Care was taken to not touch seeds and to leave no indication of our digging visible to the human eye. To detect whether cached seeds were being moved and recached, we conducted 3 separate surveys over the following 2 months (until 11 November) of the area extending out over $60 \mathrm{~m}$ from the source tree, covering approximately 0.75 ha for each survey.

As a result of the long-term tracking, we located a large number of radio-labeled seeds in a chipmunk den on 15 November 2000 . We used these labeled seeds to reconstruct the spatial and temporal dynamics of seeds moved from scatter-hoarded caches into a larder. We excavated and collected the nest and its contents on 18 November. We separated the labeled pine seeds in the field and recorded the numbers on each seed. The rest of the larder was taken to a laboratory at the University of Nevada in Reno, where other seeds were separated, counted, and weighed. We used the numbers on seeds to reconstruct spatial and temporal patterns of scatter-hoarding behavior and larder formation. Using map coordinates, we calculated the minimum distance chipmunks moved seeds from the source tree to cache sites, between successive cache sites occupied by the same seed, and from cache sites to the winter larder. If rodents moved 2 or more seeds together, only 1 distance was recorded. 
TABLE 1. Caloric contents and sizes of seeds found in yellow-pine chipmunk larders.

\begin{tabular}{lccc}
\hline Species of seed & $\mathrm{kJ} \cdot \mathrm{g}^{-1}$ (edible mass) & Kernels $\cdot \mathrm{g}^{-1}$ & Source \\
\hline Pinus jeffreyi & 25 & 11 & Vander Wall 1995 \\
Pinus albicaulis & 27 & 12 & Smith 1968 \\
Pinus contorta & 26 & 216 & Smith 1968 \\
Pinus lambertiana & 27 & 7 & this study \\
Pinus ponderosa & 32 & 31 & Smith 1968 \\
Purshia tridentata & 36 & 136 & Jenkins 1988 \\
Arctostaphylos patula & 31 & 218 & this study \\
Ceanothus velutinus & 29 & 457 & this study \\
Phacelia heterophylla & 27 & 828 & this study \\
Elymus spp. $^{\text {Castanopsis sempervirens }}$ & 12 & 300 & Roundy et al. 1983 \\
Helianthus annums $^{\mathrm{a}}$ & 22.5 & 2 & Roth and Vander Wall 2005 \\
Panicum miliaceum $^{\mathrm{a}}$ & 27 & 32 & Hullar et al. 1999 \\
Sorghum spp. $^{\mathrm{a}}$ & $18^{\mathrm{b}}$ & $202^{\mathrm{b}}$ & Hullar et al. 1999 \\
\hline
\end{tabular}

aSeeds obtained from traps

${ }^{b}$ Mean for red and white millet

\section{Larder Contents}

To find larders, it was necessary to locate chipmunks inside their winter dens. To do so, we fitted chipmunks with 2.0 -g radio-telemetry collars (Holohil Systems Ltd., Carp, Ontario, Canada; model \#BD-2C) in mid-October 2003 and 2004. Collared animals were located on a nearly daily basis between 26 October and 9 December 2003 and between 5 October and 29 November 2004. We located chipmunks by homing and marking their location with a global positioning system coordinate. When an animal was located underground in the same location on at least 3 consecutive days, we assumed that the animal had finished provisioning its larder and was dormant. At that time, we excavated its winter den and removed the animal and its winter larder. Chipmunks were taken into captivity and housed in accordance with Institutional Animal Care and Use Committee guidelines at the University of Nevada-Reno.

After the nest and larder were removed, we measured the dimensions of the nest chamber and the depth of the nest. We collected the soil surrounding nest chambers to ensure that seeds cached in the wall of the den were also collected. Larder contents and soil were spread onto cafeteria trays and allowed to air-dry. We separated seeds from soil and sorted them to species. To separate smaller seeds from the soil, we sifted samples through 5 sieves, the smallest with a pore size of $712 \mu \mathrm{m}$ that prevented loss of tiny seeds and seed fragments. All food items were weighed and counted. For the smallest seed type, we estimated the number of seeds by dividing total mass by mean seed mass, based on a sample of 100 seeds of each species. We estimated the number of eaten seeds in larders from seed shells, and we estimated the edible mass of eaten seeds before they were consumed by multiplying the estimated number of eaten seeds by mean edible seed mass.

To determine the caloric values of seeds, we reviewed the literature (Table 1). Seed species for which the caloric contents could not be found were sent to the Washington State University Wildlife Habitat and Nutrition Lab for gross caloric content analysis. We used edible mass $(\mathrm{g})$ and caloric values $\left(\mathrm{kJ} \cdot \mathrm{g}^{-1}\right)$ of each seed type to calculate caloric contents of larders. Results are presented as means with one standard deviation unless otherwise noted.

\section{Results}

Larder Formation from Scatter-hoarded Caches

Of the 209 labeled pine seeds found in the larder on 18 November 2000, 174 had legible numbers. We traced the 174 seeds to 263 scattered cache sites (Fig. 1). There were more caches than seeds because rodents frequently excavated cached seeds and moved them to new cache sites. Figure 2 illustrates the dynamics of labeled pine seeds as chipmunks moved them from the source tree to caches and eventually into the winter larder. The average seed was found at $2.6 \pm 1.1$ cache sites, with 7 seeds found at 5 cache sites and 1 seed found at 6 different cache sites. Although caches 


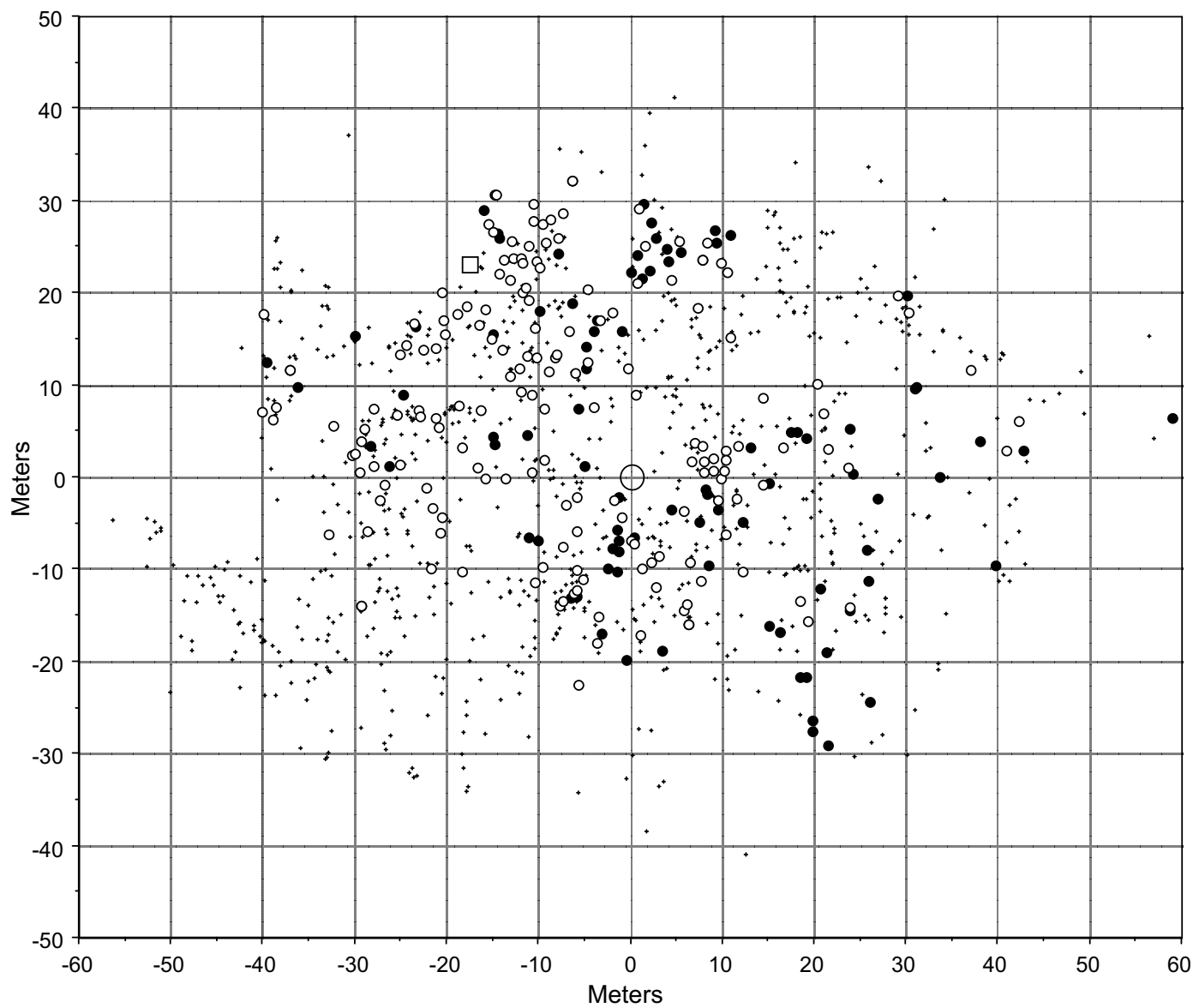

Fig. 1. A map of the study area showing source tree (large circle at origin) and winter nest and larder (square). All other symbols are cache sites: closed circles are the 94 caches from which labeled pine seeds were taken to form the winter larder; open circles are the 142 interim cache sites where larder-hoarded seeds resided temporarily during the autumn before being taken to the final 94 caches; small crosses are 800 other caches created by chipmunks using labeled seeds taken from beneath the source tree and found over a period of 2 months. Seeds from these latter caches were either eaten during autumn or they germinated in spring 2001.

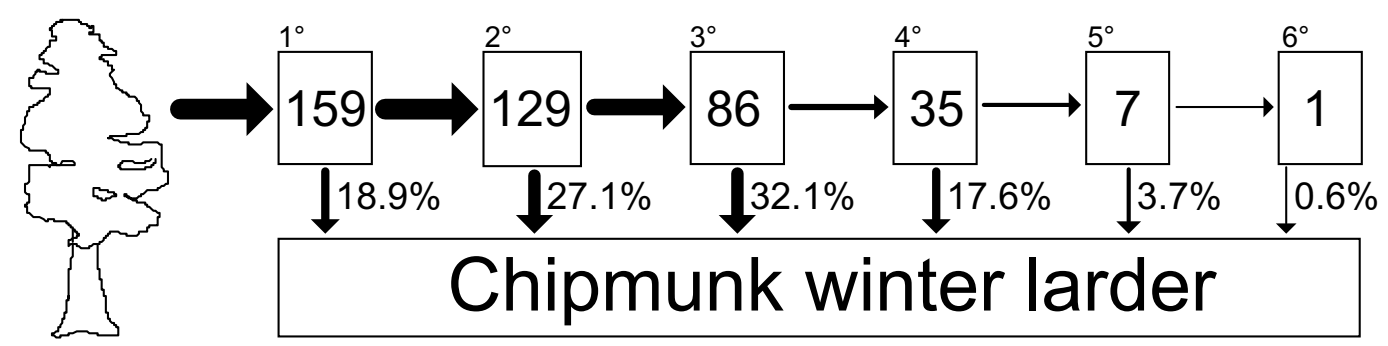

Fig. 2. Fate of labeled pine seeds taken from a source tree in 2000 that eventually were found in a yellow-pine chipmunk winter larder. Small rectangles are cache sites: primary $\left(1^{\circ}\right)$ caches contain seeds taken from the source tree and located for the first time, and secondary $\left(2^{\circ}\right)$ caches are those containing seeds taken from primary caches, etc. The size and direction of arrows show the movement of labeled seeds (numbers) between different-order cache sites. Percentages represent the contribution of labeled pine seeds from different-order caches to the winter larder. 


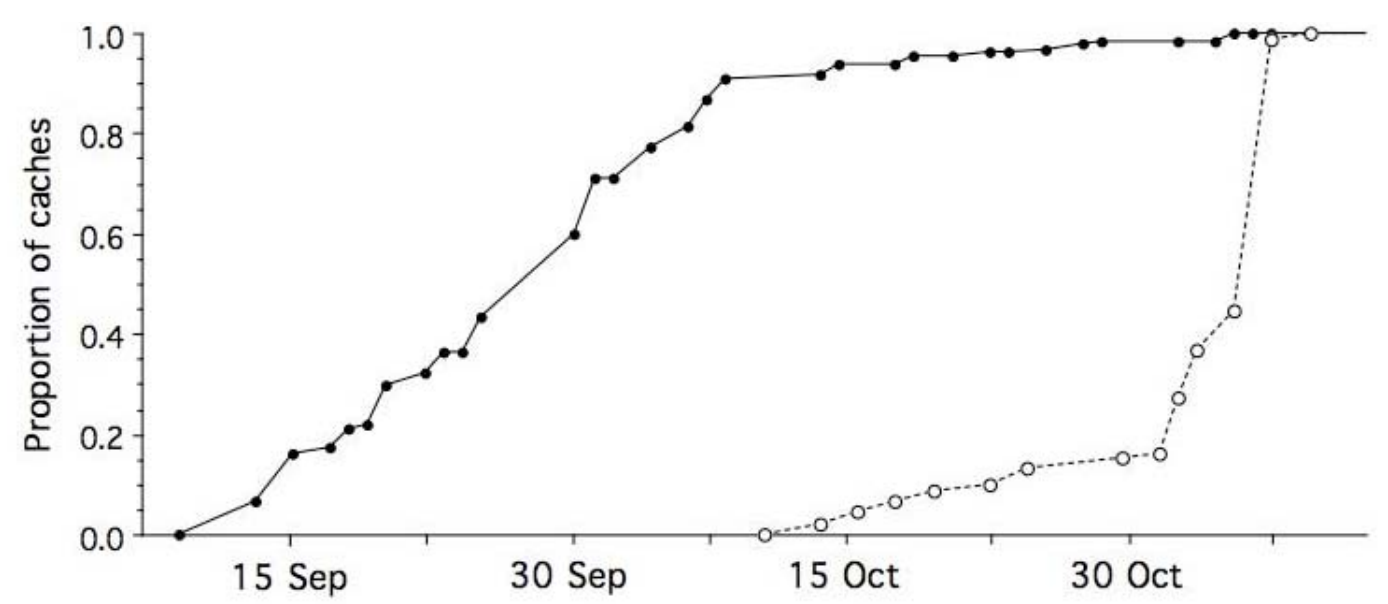

Fig. 3. The cumulative proportion of primary caches (out of 159 caches; closed circles, solid line) found during the autumn of 2000 compared to the cumulative proportion of caches first recorded as empty that went into the chipmunk's winter larder (out of 94 caches; open circles, dashed line). Surveys for cached seeds began on 12 September, the winter larder was discovered on 15 November and excavated on 18 November.

often contained 2 or more seeds, seeds were separated, combined, or eaten by chipmunks as they moved seeds from cache site to cache site, resulting in very few seeds following the same pathway from the source tree to the larder.

Seeds, including those that eventually made it into the winter larder, were removed from cache sites that appeared to be highly dispersed around the source tree (Fig. 1). Average distance from the source tree to primary caches (the site where we first found a seed; $19.4 \pm$ $9.0 \mathrm{~m}, n=121$ ) was not significantly different than average distance between successive cache sites $(17.5 \pm 15.4 \mathrm{~m} ; n=202)$. However, the average distance between cache sites where we last recorded a seed and the larder $(34.5 \pm 17.1 \mathrm{~m} ; n=92)$ was significantly longer than the average distance to and among cache sites $\left(F_{2,412}=47.347, P<0.0001\right.$, Tukey's multiple comparison test).

The scatter-hoarded pine seeds that were moved into the winter larder were first observed missing from surface caches in late October and early November (Fig. 3). Although seeds were initially cached on the days that we deployed them (9-11 September), we found most seeds in primary caches from mid-September to mid-October.

\section{Larder Contents}

We located 6 chipmunks in their winter larders in 2003 and 8 in 2004. Dens were typically small, round chambers (diameter 13.7 $\pm 2.8 \mathrm{~cm}$ ) at the end of a single burrow (tunnel length $43.6 \pm 27.7 \mathrm{~cm}$ ). From the surface, there was no evidence of winter nests. Mean depth of nest chambers was $16.3 \pm 4.4 \mathrm{~cm}$ to the tops and $27.2 \pm 8.7 \mathrm{~cm}$ to the bottoms. Nest material had a mean weight of $14.6 \pm 4.4 \mathrm{~g}$ and was composed primarily of shredded bitterbrush bark, dry grass, feathers, and hair. Nests were constructed directly on top of food. On all but one occasion, tunnels into the nest chamber were plugged with soil, and some tunnels were backfilled to the ground surface. In 2004, one chipmunk was observed digging a new burrow in the location of its winter den (animal \#716; Table 2) 3 days before it began provisioning its larder with nesting material and food. We excavated one double-chambered nest. This den was the only den that showed evidence of being used in a previous winter. Another den contained the feces of Spermophilus lateralis, indicating that chipmunks sometimes use burrows excavated by other species as den sites.

Seeds were almost the only food items found in larders. The single larder recovered in $2000 \mathrm{had}$ an edible mass of $89 \mathrm{~g}$. Larders in 2003 and 2004 had mean edible masses of 129 $\pm 34 \mathrm{~g}$ (range 68-163 g) and 40 $\pm 22 \mathrm{~g}$ (14-86 g), respectively. In nearly all larders, pine (Pinus) seeds contributed most to the overall caloric content, with the exception of the 2000 larder, which was provisioned primarily with bitterbrush (P. tridentata) and manzanita (A. patula) 
TABLE 2. Composition and caloric content (Joules) of the larders of 15 yellow-pine chipmunks. The larder from 2000

\begin{tabular}{|c|c|c|c|c|c|c|c|c|c|c|c|c|}
\hline \multirow[b]{3}{*}{ Year } & \multirow{3}{*}{$\begin{array}{l}\text { Animal } \\
\text { number }\end{array}$} & \multirow[b]{3}{*}{ Sex } & \multicolumn{10}{|c|}{ Seed species } \\
\hline & & & \multicolumn{2}{|c|}{$\begin{array}{c}\text { Pinus } \\
\text { albicaulis }\end{array}$} & \multicolumn{2}{|c|}{$\begin{array}{c}\text { Pinus } \\
\text { contorta }\end{array}$} & \multicolumn{2}{|c|}{$\begin{array}{l}\text { Pinus } \\
\text { jeffreyi }\end{array}$} & \multicolumn{2}{|c|}{$\begin{array}{c}\text { Pinus } \\
\text { lambertiana }\end{array}$} & \multicolumn{2}{|c|}{$\begin{array}{c}\text { Pinus } \\
\text { ponderosa }\end{array}$} \\
\hline & & & Count & $\mathrm{J}$ & Count & $\mathrm{J}$ & Count & $\mathrm{J}$ & Count & $\mathrm{J}$ & Count & $t \quad J$ \\
\hline $2000^{a}$ & 1 & Unk. & 4 & 9000 & 0 & 0 & 78 & 175,500 & 54 & 208,278 & 77 & 79,464 \\
\hline \multirow[t]{6}{*}{2003} & 156 & M & 0 & 0 & 0 & 0 & 1680 & $3,780,000$ & 0 & 0 & 0 & 0 \\
\hline & 105 & M & 0 & 0 & 0 & 0 & 1651 & $3,714,750$ & 0 & 0 & 0 & 0 \\
\hline & 294 & M & 0 & 0 & 0 & 0 & 1624 & $3,654,000$ & 0 & 0 & 0 & 0 \\
\hline & 336 & M & 0 & 0 & 0 & 0 & 1123 & $2,526,750$ & 0 & 0 & 0 & 0 \\
\hline & 236 & M & 0 & 0 & 0 & 0 & 1691 & $3,804,750$ & 0 & 0 & 0 & 0 \\
\hline & 369 & $\mathrm{~F}$ & 0 & 0 & 0 & 0 & 767 & $1,725,750$ & 0 & 0 & 0 & 0 \\
\hline Mean & & & 0 & 0 & 0 & 0 & 1423 & $3,201,000$ & 0 & 0 & 0 & 0 \\
\hline \multirow[t]{8}{*}{2004} & 009 & $\mathrm{~F}$ & 282 & 634,500 & 0 & 0 & 315 & 708,750 & 0 & 0 & 0 & 0 \\
\hline & 268 & $\mathrm{~F}$ & 283 & 636,750 & 14 & 1666 & 137 & 308,250 & 0 & 0 & 0 & 0 \\
\hline & 554 & $\mathrm{~F}$ & 97 & 218,250 & 81 & 9639 & 240 & 540,000 & 0 & 0 & 0 & 0 \\
\hline & 716 & M & 220 & 495,000 & 291 & 34,629 & 267 & 600,750 & 0 & 0 & 0 & 0 \\
\hline & 604 & M & 23 & 51,750 & 666 & 79,254 & 137 & 308,250 & 0 & 0 & 0 & 0 \\
\hline & 395 & $\mathrm{~F}$ & 29 & 65,250 & 0 & 0 & 12 & 27,000 & 0 & 0 & 0 & 0 \\
\hline & 049 & M & 300 & 675,000 & 294 & 34,986 & 32 & 72,000 & 0 & 0 & 0 & 0 \\
\hline & 359 & M & 157 & 353,250 & 39 & 4641 & 295 & 663,750 & 0 & 0 & 0 & 0 \\
\hline Mean & & & 174 & 401,655 & 173 & 20,602 & 179 & 301,826 & 0 & 0 & 0 & 0 \\
\hline
\end{tabular}

a209 pine seeds were given to animals by researchers.

seeds (Table 2). In 2003, larders contained 5 native species of seeds and bait seed. Bait seed was mixed birdseed that animals removed from traps during summer trapping sessions and later stored in winter larders. In addition to the seed species found in Table 2, chipmunk \#236's larder also contained a single white fir (Abies concolor) seed. In 2004, larders contained 8 species of native seeds, bait seed, and whitebark pine (Pinus albicaulis) seeds. Whitebark pine trees do not occur in the study area. Clark's Nutcrackers (Nucifraga columbiana) gather whitebark pine seeds at higher elevations and cache them in Little Valley. All whitebark pine seeds found in larders were the result of chipmunks pilfering the caches of Clark's Nutcrackers. Larders had a mean energy content of $2108 \mathrm{~kJ}(2000), 2516 \pm 684$ $\mathrm{kJ}$ (range 1344-2972 kJ; 2003), and $997 \pm 509$ kJ (range 90-1685 kJ; 2004). Additionally, some larders in 2003 and 2004 contained small quantities of insect egg cases, insect body parts, moss, bitterbrush leaves, and rabbit feces.

\section{DisCUSSION}

Food stored in scattered caches that were made during summer and early autumn was essential for construction of winter larders by yellow-pine chipmunks. Winter larders were formed in late autumn when little unstored food was available. This pattern of behavior is clear from observations of foraging chipmunks (Kuhn and Vander Wall 2008) and from our study of radio-labeled pine seeds, which were scatter-hoarded more than 7 weeks before the winter larder was formed (Fig. 3). Many species of seeds found in larders were from shrubs and herbaceous plants that ripen in summer (Roth and Vander Wall 2005, Kuhn and Vander Wall 2008). These seed crops were depleted within 2-3 weeks of maturity. Yellow-pine chipmunks scatter-hoard these seeds as they ripen, placing food items in countless cache sites from spring until autumn. Scatterhoarded seeds are important food sources for yellow-pine chipmunks during the summer and autumn, but if these seeds were not scatter-hoarded, they would not have been available in November, when chipmunks were constructing their winter larders (Kuhn and Vander Wall 2008).

In the radioactive-seed study, we found that between initial scatter-hoarding and eventual construction of the winter larder, seed caches were not static. The average seed was recorded at 2.6 cache sites, but this is surely an underestimate of the frequency of recaching. For example, primary caches made on 9-11 September were found for the first 
was found using radio-labeled seeds; those from 2003 and 2004 were found using radio-telemetry to track chipmunks.

\begin{tabular}{|c|c|c|c|c|c|c|c|c|c|c|c|c|c|}
\hline & & & & & & & $\mathrm{ed} \mathrm{sp}$ & cies & & & & & \\
\hline $\begin{array}{l}\text { Pur } \\
\text { tride }\end{array}$ & $\begin{array}{l}\text { rshia } \\
\text { entata }\end{array}$ & $\begin{array}{r}\text { Arctost } \\
p a\end{array}$ & $\begin{array}{l}\text { taphylos } \\
\text { itula }\end{array}$ & $\begin{array}{l}\text { Castc } \\
\text { sempe }\end{array}$ & $\begin{array}{l}\text { inopsis } \\
\text { ervirens }\end{array}$ & $\begin{array}{c}\text { Ceanot } \\
\text { veluti }\end{array}$ & $\begin{array}{l}\text { hus } \\
\text { nus }\end{array}$ & $\begin{array}{r}\text { Phace } \\
\text { heterop }\end{array}$ & lia & Elymus & spp. & Bait & Total \\
\hline Count & $\mathrm{J}$ & Count & $\mathrm{J}$ & Count & $\mathrm{J}$ & Count & $\mathrm{J}$ & Count & $\mathrm{J}$ & Count & $\mathrm{J}$ & $\mathrm{J}$ & $\mathrm{J}$ \\
\hline 3846 & $1,019,190$ & 2211 & 313,962 & 31 & 348,750 & 3022 & 120 & 0 & 0 & 0 & 0 & 0 & $2,154,264$ \\
\hline 144 & 38,160 & 15 & 3 & 0 & 0 & 7 & 0.3 & 0 & 0 & 0 & 0 & 43,872 & $3,862,035$ \\
\hline 334 & 90,261 & 32 & 7 & 0 & 0 & 61 & 3 & 0 & 0 & 0 & 0 & 54,507 & $3,859,528$ \\
\hline 123 & 32,595 & 9 & 2 & 0 & 0 & 26 & 2 & 0 & 0 & 0 & 0 & 167,247 & $3,853,846$ \\
\hline 394 & 104,410 & 97 & 25 & 0 & 0 & 3132 & 125 & 0 & 0 & 0 & 0 & 11,304 & $2,642,614$ \\
\hline 131 & 34,715 & 15 & 4 & 0 & 0 & 1 & 0.1 & 0 & 0 & 0 & 0 & 87,458 & $3,926,927$ \\
\hline 48 & 12,720 & 23 & 6 & 0 & 0 & 0 & 0 & 0 & 0 & 0 & 0 & 39,092 & $1,777,568$ \\
\hline 196 & 52,144 & 33 & 8 & 0 & 0 & 538 & 22 & 0 & 0 & 0 & 0 & 67,247 & $3,320,420$ \\
\hline 89 & 23,585 & 157 & 14 & 0 & 0 & 33 & 3 & 0 & 0 & 0 & 0 & 167,832 & $1,534,684$ \\
\hline 150 & 39,750 & 90 & 9 & 0 & 0 & 0 & 0 & 0 & 0 & 0 & 0 & 374,880 & $1,361,305$ \\
\hline 122 & 32,330 & 8 & 1 & 0 & 0 & 0 & 0 & 0 & 0 & 0 & 0 & 426,955 & $1,227,175$ \\
\hline 91 & 24,115 & 0 & 0 & 1 & 11,250 & 0 & 0 & 8281 & 270 & 213 & 8 & 684,222 & $1,850,244$ \\
\hline 328 & 86,920 & 10 & 1 & 0 & 0 & 0 & 0 & 2622 & 85 & 8 & 0.4 & 80,032 & 606,292 \\
\hline 0 & 0 & 3134 & 309 & 1 & 11,250 & 1 & 0.1 & 0 & 0 & 0 & 0 & 7269 & 111,078 \\
\hline 13 & 3445 & 4386 & 543 & 0 & 0 & 95 & 10 & 0 & 0 & 0 & 0 & 24,300 & 810,284 \\
\hline 594 & 157,410 & 770 & 45 & 0 & 0 & 0 & 0 & 3657 & 119 & 173 & 6 & 49,242 & $1,228,463$ \\
\hline 173 & 45,944 & 1069 & 115 & 0 & 2813 & 16 & 2 & 1820 & 59 & 49 & 2 & 226,842 & $1,091,191$ \\
\hline
\end{tabular}

time sometime between mid-September and mid-October (Fig. 3), providing ample opportunity for rodents to move cached seeds one or more times before we first found them. Further, some of the seeds found in the larder disappeared from cache sites in late October (Fig. 3) but must have been scatter-hoarded elsewhere because the larder was not constructed until after 4 November. The frequent movement of cached seeds probably represents pilferage and recaching of seeds by other chipmunks and even other species such as deer mice (Vander Wall 2000, 2002). The caches of eastern chipmunks (T. striatus) are also dynamic, but in that species, seeds from the short-lived caches are often moved into burrows by the cache makers (Elliott 1978, Clarke and Kramer 1994).

We found that in the eastern Sierra Nevada, yellow-pine chipmunks constructed new winter dens each year and that these larders were not constructed until late autumn, just prior to winter dormancy. Only a single excavated den (1 of 15) showed evidence of being used for more than one winter. Siberian chipmunks (Tamias sibiricus) also excavate a new winter den each year (Kawamichi 1996). This behavior is in contrast to eastern chipmunks, which actively defend and occupy a single den yearround and frequently use the same burrow for multiple years (Elliott 1978).
We found no evidence that yellow-pine chipmunks made larders in spring, summer, or early fall. In the semiarid region of western Nevada, the availability of food resources is patchy. In order to find food resources, chipmunks spend the majority of their time foraging and searching for food (Kuhn and Vander Wall 2008). Yellow-pine chipmunks have been observed moving as much as $425 \mathrm{~m}$ between food patches (Kuhn unpublished data). This pattern of activity precludes chipmunks from defending food cached in larders. Previous work in our study site showed that unprotected larders were raided by pilferers and received catastrophic losses to food stores (Vander Wall et al. 2005). Radio-collared animals were seldom found in the same locations (burrows and rock and tree crevices) on the same day or on consecutive days and nights prior to immergence. If animals were larderhoarding food prior to winter provisioning, we would have expected to find chipmunks in the same locations on numerous occasions. Moreover, during $>520$ hours of observation in 2003 and 2004, yellow-pine chipmunks were never observed carrying nest material or seeds into a burrow from late summer to early autumn. In contrast, in late autumn, chipmunks were frequently observed carrying nest material and food items. It is unlikely that 
yellow-pine chipmunks provision more than one larder. In fact, one chipmunk that escaped after its winter den was excavated was never located in a new den, even after repeated snow events.

Some chipmunk species store much more food in winter larders than they could consume during the period of winter dormancy. For example, Elliott (1978) found over 20,000 kJ of food remaining in eastern chipmunk larders in the spring. This is nearly 10 times greater than the size of yellow-pine chipmunk larders at the beginning of winter (Table 2). Siberian chipmunks, like eastern chipmunks, store large quantities of acorns in their winter larders (average 596 acorns; Kawamichi 1989). If we assume that acorns average approximately $5 \mathrm{kCal} \cdot \mathrm{g}^{-1}$ (Ivan and Swihart 2000), the average Siberian chipmunk larder contains approximately 1192 kCal (approximately $4991 \mathrm{~kJ}$ ) in acorns (excluding all other seed types). In general, excess winter food stores are likely to be important for increasing spring survival, increasing reproductive success, and may also provide food in the case of future mast failures (Elliott 1978, Kawamichi 1980, Barnes 1984, Place et al. 2002). In contrast with these other species, yellow-pine chipmunks in our study area did not have larders with any significant quantity of seeds remaining in spring. We observed yellow-pine chipmunks in spring and early summer recovering scatter-hoarded caches of bitterbrush and Jeffrey pine seeds from the previous year. Chipmunks recovered Jeffrey pine seeds as late as 21 July in 2003. Seed species that remain viable in the seed bank for long periods, such as manzanita and tobacco brush (Dremann and Shaw 2002), may also be important sources of food in the spring. Chipmunk species that extensively scatter-hoard, such as yellow-pine chipmunks, likely rely less on the remnants of a winter larder during spring and more on scatter-hoarded food items stored the previous year than species that primarily larder-hoard, such as eastern chipmunks.

Seed abundance influenced the sizes and contents of winter larders (Kuhn and Vander Wall 2008). Sizes and contents of larders, however, were not influenced by the chipmunks' size or sex (Kuhn and Vander Wall 2008). Abundance of Jeffrey pine seeds at our site was high in $2003\left(257.1 \pm 182.7\right.$ cones $\cdot$ tree $^{-1}$, $n=23$ [for all 3 years]), but low in 2000 (12.6 \pm 32.2 cones $\cdot$ tree $\left.^{-1}\right)$ and $2004(22.3 \pm 23.3$ cones $\cdot$ tree $^{-1}$; Vander Wall 2002, Kuhn and Vander Wall 2008). When Jeffrey pine seeds were available, yellow-pine chipmunks stored pine seeds almost to the exclusion of all other seed types. Jeffrey pine seeds are large and are calorically profitable (Table 1 ), and when these seeds are available, chipmunks seem able to acquire adequate food stores to survive the winter (Kuhn and Vander Wall 2008). When Jeffrey pine seeds were less abundant, chipmunks stored more species of seed, many of which were small-seeded species that ripen in early and mid-summer. In 2004 overall seed production on our study site was low (Kuhn and Vander Wall 2008). During this period, it appears that chipmunks had a difficult time obtaining adequate winter provisions. Kuhn and Vander Wall (2008) estimated that these larders contained enough food stores to allow the occupants to survive only approximately 6-83 days (an average winter lasts 140 days). In addition to the small seed crops, the winter of 2004 was longer than average (approximately 158 days) with large snow accumulations.

Years with low seed production coupled with long winters may exert the greatest selective pressure on food-storing hibernators. Such times of "ecological crunch" should act to reduce the variation observed in a population in favor of a phenotype that increases overwinter survival (Wiens 1977). Chipmunks' ability to recover food items cached by other animals, such as whitebark pine seeds, may have significant implications for larder contents and winter survival. Vander Wall and Jenkins (2003) predicted that successful pilferers could gradually increase the amount of food they control if they are better than average at gaining more cached food than they lose. In addition to favoring foraging ability, long winters should also select for individuals with high digestive efficiencies and individuals that optimize the use of torpor (Humphries et al. 2001).

\section{ACKNOWLEDGMENTS}

We thank Salvatore Agosta, Jennifer Armstrong, Maurie Beck, Jenny Briggs, Laura Colgin, W. Scott Hampton, Matthew Johnson, Morgan Lind, Christopher Mattson, and Julie Roth for their help in the field. We are especially grateful to Jack Hayes for the use of his telemetry equipment and Cheryl Nowak who assisted in seed identification. Sal Agosta and 
Rob Colwell made useful comments on earlier versions of this manuscript. Parts of this research were supported by NSF grant DEB9708155 .

\section{Literature Cited}

ALLen, E.G. 1938. The habits and life history of the eastern chipmunk, Tamias striatus lysteri. New York State Museum Bulletin 314:1-122.

Aunfriev, A.I., AND G.G. ArKhipov. 2004. Influence of body weight and size on the mode of wintering in hibernators of the family Sciuridae in northeastern Russia. Russian Journal of Ecology 35:189-193.

BARNES, B.M. 1984. Influence of energy stores on activation of reproductive function in male golden-mantled ground squirrels. Journal of Comparative Physiology B 154:421-425.

BROADBOOKS, H.E. 1958. Life history and ecology of the chipmunk, Eutamias amoenus, in eastern Washington. University of Michigan, The Museum of Zoology, Miscellaneous Publications 103:1-48.

Buck, C.L., AND B.M. Barnes. 1999. Annual cycle of body composition and hibernation in free-living arctic ground squirrels. Journal of Mammalogy 80:430-442.

Clarke, M.F., and D.L. Kramer. 1994. The placement, recovery, and loss of scatter hoards by eastern chipmunk Tamias striatus. Behavioral Ecology 5:353-361.

Dremann, C.C., AND M. SHaW. 2002. Releasing the native seed bank: an innovative approach to restoring a coastal California ecosystem. Ecological Restoration 20:103-107.

ELLIOTT, L. 1978. Social behavior and foraging ecology of the eastern chipmunk (Tamias striatus) in the Adirondack Mountains. Smithsonian Contributions in Zoology 265:1-107.

French, A.R. 1988. The pattern of mammalian hibernation. American Scientist 76:569-575.

2000. Interdependency of stored food and changes in body temperature during hibernation of the eastern chipmunk, Tamias striatus. Journal of Mammalogy 81:979-985.

Geiser, F., AND R.V. Baudinette. 1990. The relationship between body mass and rate of rewarming from hibernation and daily torpor in mammals. Journal of Experimental Biology 151:349-359.

Geiser, F., S. Hiebert, and G.J. Kenagy. 1990. Torpor bout duration during the hibernation season of two sciurid rodents: interrelationship with temperature and metabolism. Physiological Zoology 63:489-503.

Hawbecker, A.C. 1940. The burrowing and feeding habits of Dipodomys venustus. Journal of Mammalogy 21:388-396.

Hullar, I., I. Meleg, S. Fekete, and R. Romvari. 1999. Studies on the energy content of pigeon feeds I. Determination of digestibility and metabolizable energy content. Poultry Science 78:1757-1762.

Humphries, M.M., D.W. Thomas, and D.L. Kramer. 2001. Torpor and digestion in food-storing hibernators. Physiological and Biochemical Zoology 74: 283-292.

. 2003. The role of energy availability in mammalian hibernation: a cost-benefit approach. Physiological and Biochemical Zoology 76:165-179.
Hut, R.A, B.M. Barnes, and S. Daan. 2002. Body temperature patterns before, during, and after semi-natural hibernation in the European squirrel. Journal of Comparative Physiology B 172:47-58.

Ivan, J.S., AND R.K. SWIHART. 2000. Selection of mast by granivorous rodents of the central hardwood forest region. Journal of Mammalogy 81:549-562.

JENKINS, S.H. 1988. Comments on relationship between native seed preferences of shrub-steppe granivores and seed nutritional characteristics. Oecologia 75: 481-482.

Jennings, T.J. 1975. Notes on the burrow systems of woodmice (Apodemus sylvaticus). Journal of Zoology, London 177:500-504

KaWAMICHI, M. 1980. Food, food hoarding and seasonal changes of Siberian chipmunks. Japanese Journal of Ecology 30:211-220.

1989. Nest structure dynamics and seasonal use of nests by Siberian chipmunks (Eutamias sibiricus). Journal of Mammalogy 70:44-57.

. 1996. Ecological factors affecting annual variation in commencement of hibernation in wild chipmunks (Tamias sibiricus). Journal of Mammalogy 77:731-744.

Kuhn, K.M., and S.B. Vander WaLL. 2008. Linking summer foraging to winter survival in yellow-pine chipmunks (Tamias amoenus). Oecologia 157:349-360.

Landry-Cuerrier, M., D. Munro, D.W. Thomas, and M.M. Humphries. 2008. Climate and resource determinants of fundamental and realized metabolic niches of hibernating chipmunks. Ecology 89:3306-3316.

Lyman, C.P., J.S. Willis, A. MaLan, and L.C.H. Wang. 1982. Hibernation and torpor in mammals and birds. Academic Press, New York.

MACLEAN, G.S. 1981. Torpor patterns and microenvironment of the eastern chipmunk, Tamias striatus. Journal of Mammalogy 62:64-73.

MCNAB, B.K. 2002. The physiological ecology of vertebrates. Cornell University Press, Ithaca, NY.

Michener, G.R. 1984. Age, sex and species differences in the annual cycle of ground-dwelling sciurids: implications of sociality. Pages 81-107 in J.O. Murie and G.R. Michener, editors, The biology of grounddwelling squirrels. University of Nebraska Press, Lincoln.

Neuhaus, P., R. Bennett, and A. Hubbs. 1999. Effects of a late snowstorm and rain on survival and reproductive success in Columbian ground squirrels (Spermophilus columbianus). Canadian Journal of Zoology $77: 879-884$.

Place, N.J., C. Veloso, G.H. Visser, and G.J. Kenagy. 2002. Energy expenditure and testosterone in freeliving male yellow-pine chipmunks. Journal of Experimental Zoology 292:460-467.

Roth, J.K., and S.B. Vander Wall. 2005. Primary and secondary seed dispersal of bush chinquapin (Fagaceae) by scatter-hoarding rodents. Ecology 86:2428-2439.

Roundy, B.A., G.J. Cluff, J.A. Young, and R.A. Evans. 1983. Treatment of inland saltgrass and greasewood sites to improve forage production. USDA General Technical Report INT-157, Ogden, UT.

Sмiтн, C.C. 1968. The adaptive nature of social organization in the genus of three tree squirrels, Tamiasciurus. Ecological Monographs 38:31-64.

Stebbins, L.L., and R. Orich. 1977. Some aspects of overwintering in the chipmunk, Eutamias amoenus. Canadian Journal of Zoology 55:1139-1146. 
Tauber, M.J., C.A. Tauber, and S. Masaki. 1986. Seasonal adaptations of insects. Oxford University Press, New York.

TEvis, L.P. 1952. Autumn foods of chipmunks and goldenmantled ground squirrels in the northern Sierra Nevada. Journal of Mammalogy 33:198-205.

Ultsch, G.R. 1989. Ecology and physiology of hibernation and overwintering survival among freshwater fishes, turtles and snakes. Biological Reviews 64:435-516.

VANDER WALL, S.B. 1995. The effects of seed value on the caching behavior of yellow pine chipmunks. Oikos 74:533-537.

. 2000. The influence of environmental conditions on cache recovery and cache pilferage by yellow pine chipmunks (Tamias amoenus) and deer mice (Peromyscus maniculatus). Behavioral Ecology 11: 544-549.

2002. Masting in animal-dispersed pines facilitates seed dispersal. Ecology 83:3508-3516.
2003. Effects of seed size of wind-dispersed pines (Pinus) on secondary seed dispersal and the caching behavior of rodents. Oikos 100:25-34.

Vander Wall, S.B., E.C. Hager, and K.M. Kuhn. 2005. Pilfering of stored seeds and the relative costs of scatter-hoarding versus larder-hoarding in yellow pine chipmunks. Western North American Naturalist 65:248-257.

Vander WaLl, S.B., AND S.H. Jenkins. 2003. Reciprocal pilferage and the evolution of food-hoarding behavior. Behavioral Ecology 14:656-667.

WiEns, J.A. 1977. On competition and variable environments. American Scientist 65:590-597.

Wrazen, J.A., And L.A. Wrazen. 1982. Hoarding, body mass dynamics, and torpor as components of the survival strategy of the eastern chipmunk. Journal of Mammalogy 63:63-72.

Received 24 May 2008

Accepted 8 May 2009 